\title{
Monetary Policy at the Effective Lower Bound: Less Potent? More International? More Sticky?
}

\begin{abstract}
This paper discusses whether monetary policy at the effective lower bound (ELB) is less effective, generates greater international spillovers, or is "stickier" than conventional monetary policy. It argues that monetary policy at the ELB can be potent and that there has thus far been no convincing evidence that it has greater international spillovers through capital flows and exchange rates than comparable adjustments in interest rates. It may be more challenging to raise rates off the ELB than to raise rates from higher levelspossibly due to counterbalancing effects through the exchange rate-although there are only anecdotes to support this stickiness rather than any formal, empirical evidence.
\end{abstract}

uring the 2008 global financial crisis, many advanced economies lowered their policy interest rates to their effective lower bounds (ELBs). In some countries, these interest rates are still there. In the future, there is a good chance that many central banks will operate at the ELB more often, especially given the fall in the global neutral interest rate $\left(r^{*}\right)$ and the high probability that the next slowdown will come before interest rates are raised to levels from which they could be lowered enough to provide a substantial stimulus. Understanding how monetary policy at the ELB is different from "conventional" monetary policy is therefore critical for thinking about monetary policy in the future.

This paper explores three ways in which monetary policy at the ELB may differ from more "conventional" monetary policy—defined as primarily

Conflict of Interest Disclosure: The author did not receive any financial support from any firm or person for this paper or from any firm or person with a financial or political interest in this paper. She is currently not an officer, director, or board member of any organization with an interest in this paper. 
consisting of changes in the central bank's main policy rate. First, it asks whether monetary policy at the ELB is less effective, making it difficult for the central back to meaningfully support the economy. Second, it asks if monetary policy at the ELB has larger international spillovers- through larger effects on the volume and volatility of capital flows or on exchange rates. Third and finally, it discusses whether the ELB is "sticky," in the sense that adjustments in monetary policy around the ELB generate disproportionate feedback effects that make it harder to tighten this policy.

Each of these questions addresses concerns that have been raised about monetary policy at the ELB - concerns that could provide reasons to adjust monetary frameworks in order to reduce the probability of reaching the ELB in the future. I do not venture into this broader debate, but simply focus on whether these arguments for concern about the ELB are valid. My attempts to answer these questions are far from definitive; if anything, the discussion suggests the need for more careful analysis of these important questions.

The preliminary evidence, however, suggests that these concerns about the ELB may be overstated. Monetary policy made with "unconventional tools" can be effective at the ELB, assuming there are no political constraints on using these tools. There is also little convincing evidence to date that monetary policy at the ELB has greater international effects than would occur through comparable adjustments in interest rates on the volume or volatility of capital flows, or on exchange rates. Whether raising interest rates after being at the ELB is more challenging than raising rates from more normal levels is an open question-and one that has been even harder to answer, given the small number of countries that have thus far successfully exited the ELB. In fact, all these questions are difficult to answer because any changes in the effectiveness and channels of monetary policy since the 2008 crisis could reflect changes related to operating at the ELB - or the many other structural changes in the global economy that have occurred over this period. On a more positive note, if the current improvement in global growth and inflation continues, there should be more examples of countries exiting the ELB and therefore more evidence to help answer these questions.

\section{Is Monetary Policy at the ELB Less Potent?}

One of the concerns most frequently cited about central banks operating at the ELB is that they will not have sufficient ammunition to provide a stimulus in response to the next slowdown. In the decades before the 2008 crisis, 
adjustments to interest rates were the primary tool used by central banks to stimulate the economy. For example, in the United Kingdom, there were eight business cycle slowdowns from 1980 through 2010, during each of which the Bank of England reduced interest rates by an average of 3.75 percentage points. ${ }^{1}$ In the United States, there were seven business cycle slowdowns over the same period, and the U.S. Federal Reserve reduced interest rates by an average of 4.59 percentage points. If interest rates are at the ELB, then these types of reductions will not be possible. If central banks cannot provide stimulus through other mechanisms, and if fiscal policy is constrained due to high deficits or political constraints, countries could face periods of slower and more volatile growth. This is a key concern behind arguments to adjust inflation targets and reduce the probability of being at the ELB.

One challenge to this line of reasoning, however, is that reductions in interest rates are not the only channel by which central banks can provide stimulus. The global financial crisis of 2008 and the subsequent prolonged recovery, combined with monetary policy at the ELB in many advanced economies, prodded many central banks to experiment with other forms of stimulus. Some were more potent than others, and the effectiveness of many is still widely debated. ${ }^{2}$ Some policies that seemed to be effective at the time may have worked due to specific characteristics of the crisis period (such as poor market liquidity), so that they would be less effective in stimulating the economy during less stressed periods.

Nonetheless, my experience on the Monetary Policy Committee (MPC) at the Bank of England convinced me that these unconventional tools can be effective, even outside crisis periods. In fact, central banks can stimulate the economy in a number of ways when at the ELB-even if most central bankers (myself included) would prefer to return to an era when adjustments in monetary policy were made primarily through adjustments in interest rates.

More specifically, before I joined the MPC in 2014, the Bank of England had embarked on several rounds of quantitative easing from 2009 to 2012. ${ }^{3}$ Most studies of this experience suggest that this provided a meaningful stimulus to the U.K. economy. For example, Martin Weale and Tomasz

1. For the details of these calculations, see Forbes (2015).

2. For a summary of the evidence, and more skeptical view of the effectiveness of asset purchases in the United States, see Greenlaw and others (2018).

3. For information on these programs and different estimates of their effects, see Joyce, Tong, and Woods (2011) and Haldane and others (2016). 
Wieladek (2016) estimate that, on average over this period, asset purchases worth 1 percent of GDP boosted U.K. GDP by about 0.25 percent. This estimated impact of asset purchases worth 1 percent of GDP is roughly equivalent to the impact of a reduction of 25 basis points in the Bank Rate (the policy interest rate set by the Bank of England) on U.K. GDPaccording to very rough rules of thumb. Total asset purchases as of 2012 were $£ 375$ billion, equivalent to about 20 percent of the U.K.'s GDP at the time, which would imply a boost to GDP of about 5 percent - the equivalent of reducing the Bank Rate by 5 percent. Of course, these are only rough estimates and do not incorporate the many other factors that were affecting the economy at this time; but even if they are off by half, they still suggest that monetary policy at the ELB was able to provide a meaningful stimulus.

I admit, however, that I was always skeptical of these types of estimates, especially given that some of the large estimated benefits from quantitative easing (QE) over this period likely arose from its ability to improve the liquidity and functioning of stressed financial markets. Would QE provide a similar stimulus when markets were functioning well? This was a critical question for the MPC in 2016, after the U.K. voted to leave the European Union (the "Brexit" vote), and most surveys suggested that economic growth would slow sharply. The policy interest rate was near what was then believed to be the ELB, and the majority of the MPC's members wanted to provide more support for the economy than could be achieved by lowering interest rates to the ELB. Were there other monetary policy tools that could provide a meaningful stimulus at this time?

In August 2016, the majority of the MPC's members voted for a four-pronged easing program: to reduce Bank Rate by 25 basis points; to purchase an additional $£ 60$ billion in government bonds; to purchase $£ 10$ billion in corporate bonds; and to start a Term Funding Scheme (TFS) that would provide contingent and targeted funding for banks to encourage them to pass on the reduction in Bank Rate to borrowing costs for businesses and households. The Bank of England's staff simulated the effects of this four-pronged package under model assumptions that the asset purchase programs would provide some stimulus, but less than the average effects from earlier rounds of QE. The reduction in Bank Rate was expected to account for less than one quarter of the total stimulus from the package - with most of the stimulus resulting from the additional purchases of government bonds. If interest rates were not at the ELB, the MPC would have had to lower Bank Rate by roughly 100 basis points to get the same estimated aggregate effect on GDP growth and inflation. 
Table 1. U.K. Financial Market Indicators after the August 2016 Stimulus

\begin{tabular}{lcc} 
& \multicolumn{2}{c}{$\begin{array}{c}\text { Cumulative change between } \\
\text { August 3, 2016, and: }\end{array}$} \\
\cline { 2 - 3 } Indicator & -17 & -11 \\
\hline $\begin{array}{l}\text { Uugust 4, 2016 } \\
\text { Sterling investment-grade corporate bond }\end{array}$ & -10 & -17 \\
$\quad$ spreads (basis points) & -8 & -20 \\
$\begin{array}{l}\text { Sterling high-yield corporate bond spreads } \\
\quad \text { (basis points) }\end{array}$ & & 4.2 \\
$\begin{array}{l}\text { FTSE All-Share (index) } \\
\text { U.K.-focused companies' equity prices } \\
\quad \text { (index: August 3, 2016 = 100) }\end{array}$ & 0.9 & 2.2 \\
$\begin{array}{l}\text { Sterling Exchange Rate Index } \\
\quad \text { (January 2005 = 100) }\end{array}$ & -1.3 & -2.9 \\
\hline
\end{tabular}

Source: Bank of England (2016, box on 2-3).

Although it is impossible to estimate the exact effects of this program, and especially the effects of its individual components because their joint announcement may have amplified their impact, the available evidence suggests that the asset purchase programs and TFS provided a meaningful amount of stimulus to the economy. In fact, they appear to have provided an even larger boost than expected. For example, the Bank of England analyzed financial market data in the period after the package was announced and concluded that "if anything, the impact was slightly greater than had been anticipated." Although the reduction in interest rates had largely been priced in before the announcement of the four-pronged package, table 1 shows that other market prices (which primarily reflect the impact of the "unconventional" components of the package) adjusted in ways that would support the economy. The sterling Exchange Rate Index depreciated, and the spread on 10-year gilt yields and various corporate bonds fell. The Financial Times Stock Exchange (known as FTSE) All-Share Index and equity prices for U.K.-focused companies increased. Funding costs of U.K. banks also decreased (likely supported by the TFS). All these price adjustments are in the same direction that traditionally follows an unexpected easing in monetary policy, suggesting that the unexpected and unconventional components of the four-pronged package also acted to ease financial conditions.

4. See Bank of England (2016, box on 2-3). 
Although it is difficult to directly connect these developments to changes in the real economy, these movements in financial indicators are key channels by which a monetary stimulus traditionally supports economic growth and inflation. Data for the subsequent year also suggest that the package supported the economy in ways that would normally occur from easing monetary policy when not constrained by the ELB. For example, retail interest rates for households and businesses fell. ${ }^{5}$ Lena Boneva, Calebe de Roure, and Ben Morley (2018) estimate that the corporate bond purchase program reduced the spreads of eligible bonds by 13 to 14 basis points (compared with foreign bonds issued by the same set of firms), and boosted values for other U.K. assets that were not eligible for the purchase program.

All these estimates are imprecise; it is impossible to know the counterfactual, and different monetary tools will undoubtedly have different effects in different economies (as well as different effects at different times in the same economy). Nonetheless, they suggest that central banks do have tools available to stimulate the economy other than lowering interest rates. As a result, central banks are not necessarily "out of ammunition" just because they are at their ELB. Of course, there are also constraints on these types of unconventional policies. For example, asset purchases will be limited by the size of the relevant asset market, and political constraints could limit the ability of some countries to use these types of unconventional tools (such as in the United States). Nonetheless, the fact these tools are available, and that they can be potent even when markets are functioning well, should alleviate some of the concerns about the potency of monetary policy at the ELB.

\section{Is Monetary Policy at the ELB More International?}

A second common concern about monetary policy at the ELB is that it works through different channels than traditional monetary policy. There are a range of ways this could occur. For example, if monetary policy at the ELB is done more through forward guidance, then it could have larger effects on the longer end of the yield curve (relative to those on short-term rates) than occurs with adjustments in policy rates. Or, if monetary policy at the ELB is adjusted more through asset purchases, it could have greater effects on specific asset prices and therefore have different distributional implications. Here, however, I focus on two ways in which monetary

5. Ibid. 
policy at the ELB could have greater effects through international channels, and thereby generate larger global spillovers. ${ }^{6}$ More specifically, do interest rates at the ELB in advanced economies stimulate excessive volumes or volatility in capital flows to other countries? And when countries are at the ELB, do adjustments in monetary policy have greater effects on the exchange rate?

\section{II.A. Capital Flows around the ELB}

Prominent policymakers in emerging markets have complained that $\mathrm{QE}$ and near-zero interest rates in major advanced economies stimulate excessive capital flows to emerging markets-which have been described in colorful terms as "currency wars" by Guido Mantega (Brazil's former finance minister) and as a "monetary tsunami" by Dilma Rousseff (Brazil's former president). They argue that these "surges" of capital flows can lead to challenges, such as elevated asset prices and currency appreciation, and also increase vulnerabilities from the inevitable "sudden stop" when the abundant capital inflows reverse. There is no doubt that volatile capital flows create challenges for emerging markets-especially those with weaker institutions and financial systems. There is also evidence that monetary policy in advanced economies is an important driver of global capital flows, although most research suggests that it is only one of a number of factors driving capital movements (with other variables, such as global risk, often being more important). ${ }^{7}$ The key questions, however, are if interest rates near the ELB in advanced economies tend to aggravate the surges in capital flows to emerging markets, and if they exacerbate excess volatility in capital flows.

It is difficult to test these hypotheses formally, partly due to the limited episodes at which interest rates in major economies have been near the ELB, and partly because there is no clear benchmark for determining the optimal level of capital flow volumes or volatility. Nonetheless, as an informal test, it is useful to look at recent patterns in capital flows to assess if they appear to have been elevated or more volatile during the last decade, when interest rates in advanced economies have often been at the ELB.

6. Monetary policy at the ELB could also generate international spillovers by affecting foreign market prices. For analyses of whether these spillovers differ when monetary policy is conducted through QE or adjustments in interest rates, see Curcuru and others (2018). Most research finds no consistent differences in the spillovers from conventional and unconventional monetary policy.

7. See Forbes and Warnock (2012) and Rey (2013). 
Figure 1. Capital Inflows to Emerging Markets as a Percentage of Emerging Market GDP, 2000-2016

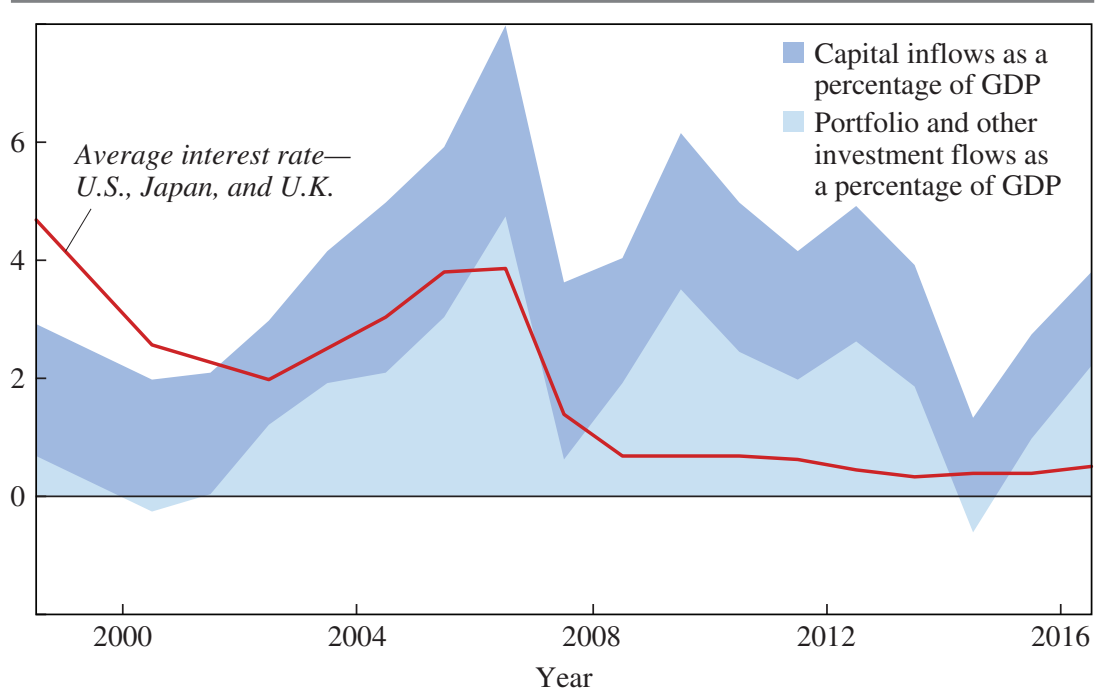

Sources: For capital flow data, the Emerging Market Capital Flows database of the Institute of International Finance, May 2018; for GDP and interest rate data, the International Monetary Fund's World Economic Outlook database, April 2018.

a. Capital inflows are nonresident capital flows (changes in liabilities) to emerging markets as a percentage of emerging market GDP. These include foreign direct investment, portfolio investment, and other investment. The lighter shaded area excludes foreign direct investment. The average interest rate is the average of the policy rate for the U.S. and U.K. and discount rate for the euro area and Japan in each year.

Figure 1 shows a first piece of evidence: gross global capital inflows to emerging markets as a percentage of emerging market GDP from 2000 through $2017 .{ }^{8}$ The figure also shows the average interest rate set by four major central banks (the U.S. Federal Reserve Board, European Central Bank, Bank of England, and Bank of Japan) over this period. During the last decade, when interest rates have been around the ELB in these major economies, it is hard to make the argument that capital inflows to emerging markets have been "excessive"-at least compared with precrisis patterns.

8. Capital inflows are annual nonresident capital flows (changes in liabilities) to emerging markets, based on the Emerging Market Capital Flows database of the Institute of International Finance, May 2018. GDP and interest rate data are from the IMF's World Economic Outlook database, April 2018. The interest rate is the annual average of the policy rate for the U.S. and U.K. and the discount rate for the euro area and Japan. 
More specifically, gross capital inflows to emerging markets averaged 4.0 percent of emerging market GDP from 2010 through 2017, below the five-year average before the crisis (of 5.2 percent from 2003 to 2007). Even in 2010, when capital flows to emerging markets rebounded as many economies experienced rapid recoveries, capital inflows never reached their peak of 2006. These patterns even continue to hold for the more volatile capital flows that are more tightly linked to monetary policy (shown in the lighter shading in figure 1). ${ }^{9}$ These more volatile capital flows only averaged 1.9 percent of emerging market GDP from 2010 to 2017, as compared with 2.6 percent from 2003 to 2007. Granted, the volume of capital inflows to emerging markets may still be elevated relative to optimal levels, and may be large enough to create challenges for many countries, but the period of very low interest rates in major economies does not appear to have accelerated these flows relative to when interest rates were higher.

Many emerging markets, however, are more concerned about the volatility in capital inflows than about the volumes, and especially the occurrence of "sudden stops" and "surges" of capital inflows. Therefore, to assess whether capital flows to emerging markets are more volatile around the period of interest rates at the ELB in advanced economies, I use the technique developed by Forbes and Francis Warnock (2012) to calculate the occurrence of surges and sudden stops in capital flows from abroad, based on whether there are unusually large increases or decreases in foreign capital flows relative to historic country-specific trends. More specifically, this methodology uses gross quarterly capital inflow data and defines a "surge" as a period that includes an increase in year-over-year changes in fourquarter gross capital inflows that is more than 2 standard deviations above the historic average for at least one quarter. A "sudden stop" is defined symmetrically, requiring a decrease in gross capital inflows that is more than 2 standard deviations below the historic average. ${ }^{10}$

Figure 2 shows the share of the sample that experienced surges and stops from 1985 through 2017, using updated data and a slightly different sample from when this methodology was introduced by Forbes and

9. More volatile capital flows are defined as portfolio flows and "other" investment flows, the latter of which are largely bank flows. They exclude foreign direct investment.

10. Each surge and stop episode is defined as lasting for all consecutive quarters for which the year-over-year change in annual gross capital flows is more than 1 standard deviation above or below the historical average. The length of each episode is required to be greater than one quarter. Data are primarily from the IMF's International Financial Statistics, supplemented with country sources. See Forbes and Warnock (2012) for details. 
Figure 2. The Incidence of Surges and Stops of Capital Flows from Abroad, October 1985-October 2017

\section{Surges}

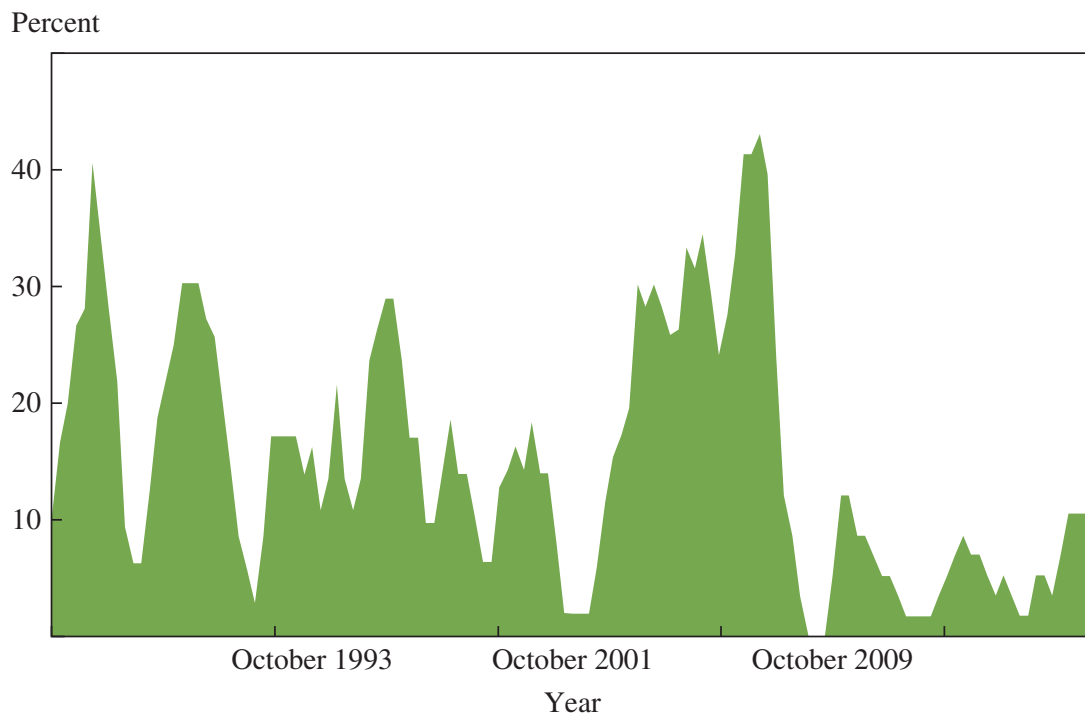

\section{Sudden stops}

Percent

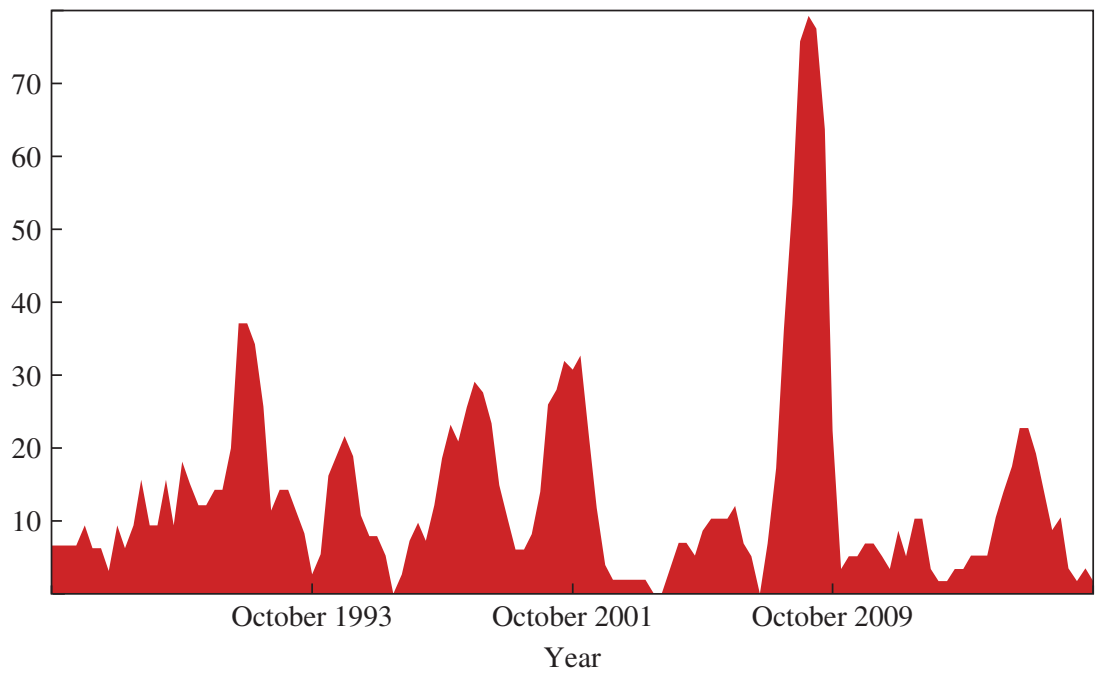

Sources: The underlying data are primarily quarterly capital flow data from the International Monetary Fund's International Financial Statistics, supplemented with country sources.

a. This figure shows the percentage of countries in the sample experiencing a surge or sudden stop in capital inflows from abroad each quarter. The methodology is discussed in the text and is described in more detail by Forbes and Warnock (2012). 
Warnock (2012). The figure's top panel does not suggest any increase in the share of countries experiencing surges of capital inflows during the period of interest rates near the ELB in advanced economies. In fact, capital flow surges are even less frequent since 2009 than during the 1990s, and much less frequent than during the period of relatively high interest rates preceding the 2008 crisis. The bottom panel also suggests that there was not an unusual number of sudden stops. Although the incidence of sudden stops increased around the "taper tantrum" in 2013-14 (to peak at about 20 percent of the sample), this was not unusual when compared with the cycles experienced over the 20 years before the 2008 crisis - a period when interest rates in major economies were not near the ELB.

\section{II.B. Exchange Rate Sensitivity around the ELB}

Even if interest rates around the ELB do not seem to have generated an unusually large volume or increase in the volatility of capital flows, adjustments in monetary policy around the ELB could still be generating unusual international spillovers through their effects on exchange rates. This is another angle of the concerns about "currency wars"; unconventional monetary policy could have greater effects on the exchange rate than a comparable stimulus provided through changes in policy interest rates. (In fact, a larger effect on the exchange rate could mute the subsequent adjustments in capital flows.) These concerns were serious enough that they were the topic of a Group of Seven meeting in 2013 and were discussed at the group's resulting special statement establishing ground rules to address the potential effects on exchange rates of different monetary policy tools. ${ }^{11}$ The research of Christopher Neely (2015) is frequently cited as evidence supporting these concerns; it finds that the U.S. Federal Reserve's announcements of QE had larger effects on the dollar than non$\mathrm{QE}$ announcements. This analysis, however, does not control for the fact that the average stimulus provided by the $\mathrm{QE}$ announcements was larger than that by the non-QE announcements.

Nonetheless, there are reasons why unconventional monetary policy could have larger effects on exchange rates than a comparable stimulus provided by adjusting interest rates. Unconventional monetary policy appears to work more through the term premium (and therefore long-term securities), whereas conventional monetary policy works more through shortterm rates (and therefore money market rates). Unconventional monetary

11. See Group of Seven (2013). 
policy may be interpreted as a longer-term commitment to a path of monetary policy over a longer period, whether in the form of a commitment to asset purchases over an indefinite period or state-contingent forward guidance. Any of these channels could cause a monetary stimulus at the ELB to have a larger effect on the exchange rate than more conventional changes in policy interest rates. This could, in turn, generate greater spillovers and challenges for any emerging markets that subsequently experienced sharp currency appreciations. ${ }^{12}$

Whether monetary policy at the ELB has a larger effect on exchange rates is an important question-but one that is extremely difficult to identify and test. Several papers (such as the one by Glick and Leduc 2015) have tried to assess one piece of the puzzle: if exchange rates respond differently to changes in short-term than long-term rates. These papers generally find no significant difference, although identification is a challenge, given that movements in short-term rates tend to correspond to movements in long-term rates. Several studies (Glick and Leduc 2015; Curcuru 2017; Ferrari, Kearns, and Schrimpf 2017) have also found that the responsiveness of the dollar to U.S. monetary policy announcements or U.S. monetary policy surprises rose after the 2008 crisis. This could have resulted from structural changes not directly related to the form of monetary policy, however, which may have made the dollar more responsive to all forms of monetary policy over the last decade.

Stephanie Curcuru and others (2018) and Jan Hatzius and others (2017) take a different approach - and find somewhat different (albeit not contradictory) results. Curcuru and others (2018) tackle the identification challenge by assuming that asset purchases affect the term premium (and therefore longer-term bond rates), whereas conventional monetary policy only affects short-term rates. Based on this assumption, it finds that QE does not generate significantly larger spillovers (in terms of dollar movements, as well as other financial market measures) than conventional monetary policy. Instead, it finds evidence of the opposite: that a given increase in expected interest rates has more than double the effect on the dollar than the same increase in the term premium (which is assumed to be accomplished through asset purchases). Hatzius and others (2017) reach similar conclusions in an analysis that regresses exchange rates on components of the yield curve and also assumes a larger effect of asset purchases on the

12. Brainard (2017) has an excellent discussion of these issues. It models the different spillovers from adjusting interest rates versus asset purchases, and shows how the spillovers will vary based on the country's exchange rate regime and output gap. 
term premium. Two challenges to these studies, however, are the restrictiveness of the identification assumptions and the lack of a broader understanding of what has been causing movements in the term premium over the last decade.

All in all, whether unconventional monetary policy used at the ELB has a larger effect on exchange rates than a comparable adjustment in monetary policy made through interest rates is still an open questionand a prime target for future research. Although there are valid arguments why monetary policy at the ELB could have larger international effects through exchange rates, as well as through the volume and volatility of capital flows, there is little convincing evidence to date that this has occurred.

\section{Is Monetary Policy at the ELB More Sticky?}

A closely related issue is whether exchange rate adjustments at the ELB make it more difficult to raise interest rates and exit the ELB. More specifically, does the first increase in the policy interest rate from the ELB - or even providing guidance on the intent to do so-cause a larger exchange rate appreciation than would occur for a comparable increase in interest rates from a higher starting point? Because appreciations tend to reduce import price inflation and headline inflation (especially when the appreciation corresponds to a monetary policy shock, as shown in Forbes and others 2018), the subsequent drag on inflation could make it more difficult to justify an increase in interest rates. If the appreciation caused by forward guidance of a forthcoming exit from the ELB were large enough, it could even prevent the exit from the ELB. Or, if a large appreciation were caused by the first increase in interest rates off the ELB, it could make it more difficult to raise interest rates againleading to an unusually slow tightening cycle. In other words, does excessive exchange rate sensitivity around the ELB make interest rates more "sticky"?

Although there has been no empirical work assessing these effects (to the best of my knowledge), my experience at the Bank of England suggests that the ELB may in fact be "sticky." More specifically, when I started on the MPC in July 2014, the MPC had recently provided guidance that raised expectations that Bank Rate would soon be increased-the first increase in the policy interest rate since 2009. The top panel of figure 3 shows market expectations for U.K., U.S., and euro area interest rates about that time, indicating that investors expected this increase in U.K. 
Figure 3. Expected Interest Rates and the Sterling Exchange Rate in 2014

\section{Market expectations for interest rates}

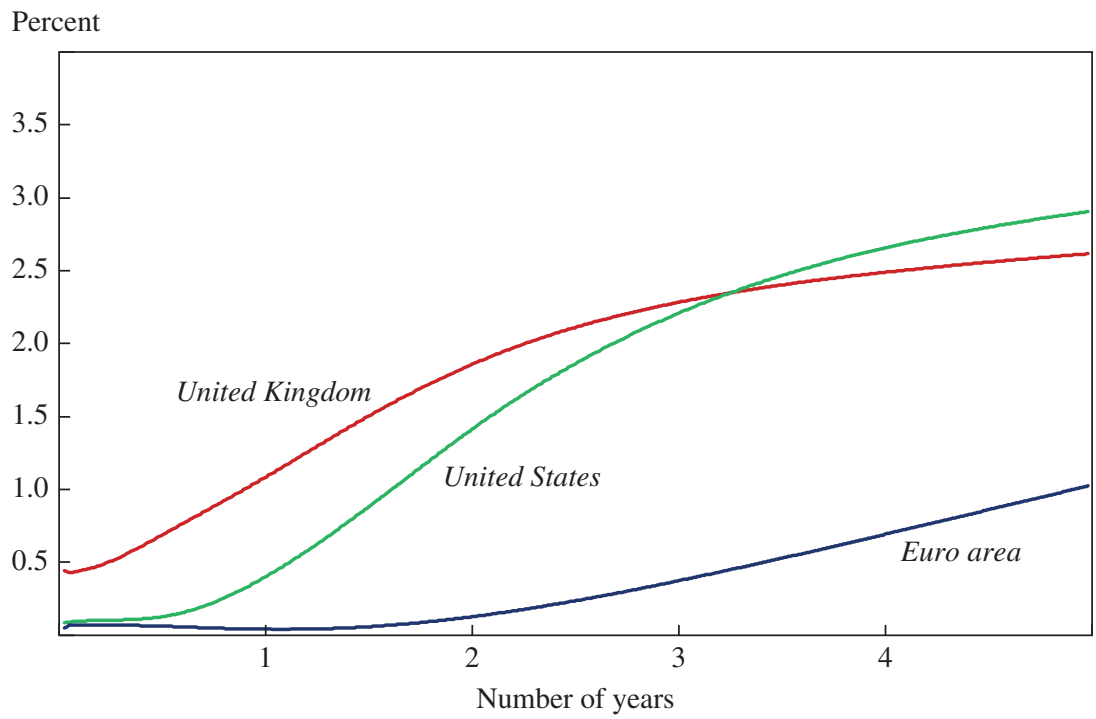

Index

\section{Sterling exchange rates}

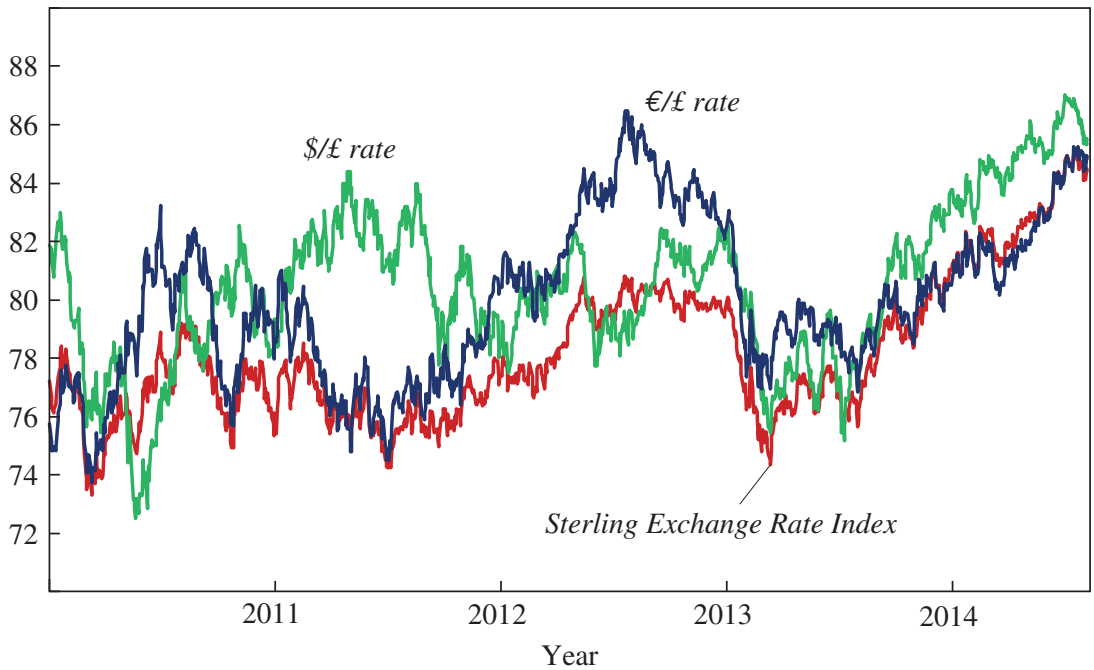

Source: Based on data from the Bank of England (2014).

a. Curves of market expectations for interest rates are estimated using instantaneous forward overnight index swap rates in the 15 working days to August 6, 2014. The Sterling Exchange Rate Index is based on January 2, $2007=100$. 
rates to occur within the next six months. ${ }^{13}$ Sterling had also been appreciating sharply (the bottom panel of figure 3 ) -with the exchange rate index already up about 12 percent by October 2014 (from its recent low in March 2013). This appreciation would continue over the next few months (peaking at over 15 percent) and have a number of effects on the economy. For example, it contributed to tighter financial conditions and slower growth in net exports - both of which would be a drag on GDP growth and therefore inflation in the future. The currency appreciation was also expected to reduce import prices and Consumer Price Index (CPI) inflation. Using the Bank of England's rough rule of thumb at the time, a 12 percent appreciation would be expected to reduce the level of import prices by about 11 percent and the CPI by over 3 percent over the next few years-very large effects. ${ }^{14}$

Moreover, these effects of sterling's appreciation on inflation were expected to have first-order importance for the appropriate path for monetary policy. Figure 4 shows the results of a simulation I did at that time (in Forbes 2014), using the more complicated dynamic stochastic general equilibrium model used by the Bank of England to capture the full effects of the appreciation, combined with data on the economy that existed in October 2014. ${ }^{15}$ The MPC inflation forecast (the red line) incorporated the effects of sterling's sharp appreciation to date. This forecast suggested that inflation would remain below the 2 percent inflation target over the next year, implying that interest rates would not need to be tightened as much or as quickly as suggested by the market curve. In contrast, the simulated path of inflation (the black line) assumes that sterling did not appreciate and instead remained at its 2013:Q1 level. The simulation predicts that inflation would have been well over the 2 percent target for the next few years.

13. Market expectations are measured by instantaneous forward overnight index swap rates from Haver and the Bank of England.

14. The rule of thumb at the time was that the pass-through from movements in the sterling Exchange Rate Index was 90 percent to import prices and then 30 percent to headline CPI (so that a 10 percent depreciation corresponds to a 9 percent increase in the level of import prices and 3 percent increase in the level of the CPI). This rule of thumb was subsequently adjusted so that the pass-through to import prices was reduced to 60 percent (and there was no change in the second stage of the pass-through).

15. This simulation compares the path of CPI inflation predicted in the latest Inflation Report relative to a situation in which the exchange rate had remained at its 2013:Q1 level and there had been no other shocks or changes in policy. The shift in the exchange rate is assumed to result from an exogenous exchange rate shock, and the shaded bands around the black line capture the range of outcomes based on different assumptions for the persistence of the appreciation. 
Figure 4. U.K. Inflation Forecast and Simulated Inflation Path Assuming No Sterling Appreciation, 2013:Q1-2016:Q1

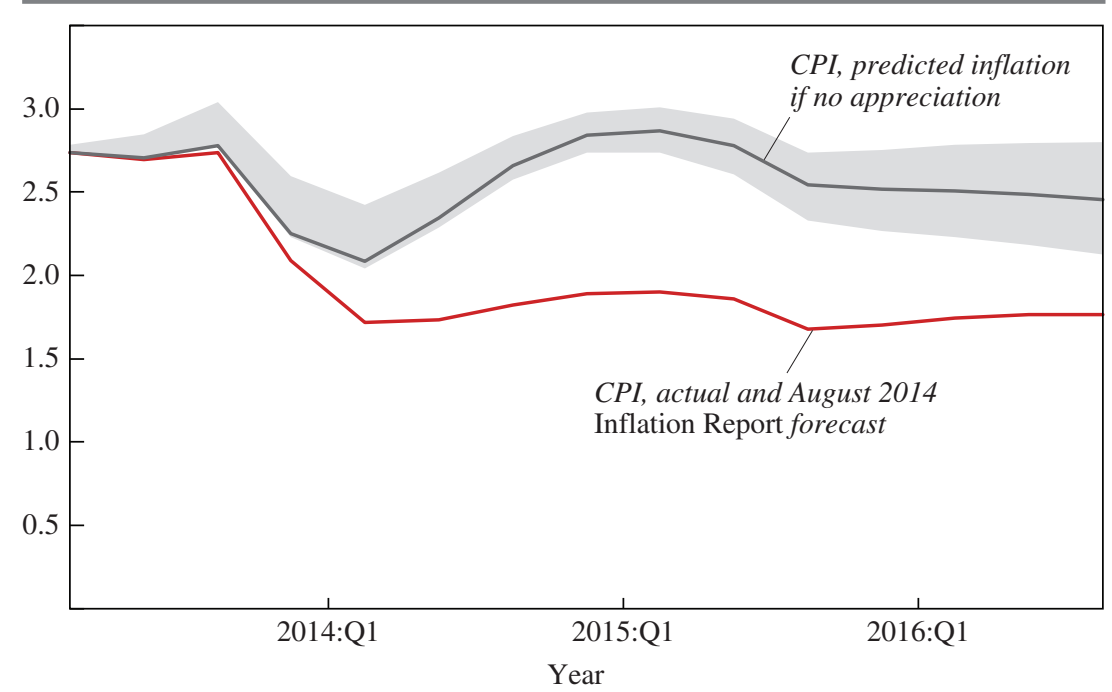

Source: Forbes (2014).

Note: CPI = Consumer Price Index. The shaded area is COMPASS's predictions of CPI inflation if the exchange rate remained at its 2013:Q1 level, under assumptions of different degrees of persistence of the appreciation. The appreciation is assumed to be exogenous, with no other changes in policy and no other shocks.

Although it is impossible to know what the MPC would have decided in this counterfactual situation, it is likely that interest rates would have been lifted off the ELB sooner if the exchange rate had not appreciated so sharply and substantially dampened the expected path of inflation. Instead, exit from the ELB was delayed for an extended period-and the next move in U.K. interest rates was actually down (after the Brexit vote) instead of up. U.K. interest rates were only lifted above 0.5 percent in August 2018four years after this period of serious consideration of exiting from the ELB. Granted, much of this delay was due to other subsequent shocks (such as the sharp decline in commodity prices in 2015 and uncertainty about the Brexit vote), but the initial move off the ELB would likely have occurred before these additional shocks if sterling had not appreciated so sharply when interest rates were at the ELB.

Of course, sterling would still have appreciated if the expected 2014 increase in interest rates occurred at a level of interest rates above the ELB. The key question is whether the appreciation during this episode was larger 
than it would have been if rates were not at the ELB. This is a more difficult question to answer, but a comparison with historic episodes suggests that sterling was more sensitive than would normally be expected. More specifically, an increase of 25 basis points in interest rates is usually assumed to correspond to a sterling appreciation of about 0.25 to 1 percent. ${ }^{16}$ This band reflects historic averages as well as model estimates, and suggests that the exchange rate movement in 2014 and early 2015 was meaningfully larger than would be expected based on expected changes in monetary policy.

There are several reasons why exchange rates could be more sensitive to changes in monetary policy as countries attempt to move away from the ELB. First, the initial movement away from the ELB is likely to occur through forward guidance about the near term, especially because central banks tend to be even more cautious than usual and not to want to create surprises when raising interest rates for the first time in an extended period. Forward guidance-especially if focused on imminent changes in policywould likely have a large effect on short-term interest rates, which may be more closely linked to exchange rate movements. Second, raising interest rates off the ELB after an extended period of monetary stimulus may be seen as signaling a major shift in policy, which will affect not only short-term rates but also the whole market curve, and in a stronger way than normally occurs. Similarly, it could be interpreted as showing a shift in confidence about the economic outlook, similar to the "Delphic effect" found by Emi Nakamura and Jón Steinsson (2018). Finally, the relative size of the change in interest rates when starting at such a low level may matter; for example, raising interest rates by 25 basis points is a doubling of interest rates if moving from an ELB of 0.25 percent, but only about a 10 percent increase if moving from a level of 2.0 percent. The relative increase in carry costs or other prices related to the increase of 25 basis points in interest rates could cause disproportionate effects on currency trading and other pricing.

If there is a "stickiness" to raising interest rates from the ELB, assessing the magnitude of this effect is challenging. Not only are there limited examples to assess, but any such effects will also undoubtedly differ across countries and over time. Factors that would determine the magnitude of any such stickiness include whether other countries are also tightening monetary policy at the same time; the sensitivity of the currency to interest

16. The lower estimate reflects the rule of thumb from the Bank of England's COMPASS model under a set of standard assumptions, described by Burgess and others (2013). The higher number is estimated by Forbes and others (2018). 
rates; and the sensitivity of inflation, financial conditions, and exports to exchange rate movements.

Given these challenges, it is not surprising there has not yet been a formal study of any of these channels that could make adjusting interest rates at the ELB sticky. There are, however, numerous anecdotes from countries other than the U.K., which would support the hypothesis that it has been harder to exit from the ELB than expected. For example, as of June 2017, despite seven years of solid global economic growth above 3 percent, no advanced economy (other than Hong Kong and the United States) had been able to maintain an increase in interest rates since 2011. In fact, at that time, nine countries that had tried to "lift off" and raise interest rates after 2009 had then reversed the rate increase (see Forbes 2017). Even the U.S., the advanced economy able to raise interest rates the most from its ELB, was only able to do so after a very slow start; it was a full year between the date when the U.S. Federal Reserve first raised interest rates above the ELB and its next rate increase. Granted, the simultaneous challenges for so many countries in exiting the ELB may also reflect common global developments - such as a decline in the global equilibrium interest rate. Nonetheless, it also may reflect additional challenges and a stickiness in raising interest rates from the ELB.

\section{Conclusions}

Research on monetary policy at the ELB is only in its infancy. An empirical analysis of whether monetary policy functions differently at the ELB is complicated by the fact that the last decade when many advanced economies were at the ELB coincided with many other structural economic changes - changes that would also affect the functioning of monetary policy. Nonetheless, here I have drawn on what we know to date, including my experience setting monetary policy in the United Kingdom, to assess the validity of three different concerns about monetary policy at the ELB. Is monetary policy less potent at the ELB? Does it generate greater international spillovers (through capital flows and exchange rates)? And does the ELB make monetary policy stickier and make it harder to raise rates when appropriate? The last set of concerns is more speculative, but the first two have been raised as reasons to avoid the ELB when possible-potentially justifying changes to monetary policy frameworks.

The discussion in this paper, however, suggests that monetary policy at the ELB can still be potent, and does not necessarily generate any greater 
international spillovers through capital flows and exchange rates than comparable adjustments in interest rates. It may be more challenging to raise rates off the ELB than to raise rates from higher levels-possibly due to counterbalancing effects working through the exchange rate-although there are only anecdotes to support this stickiness rather than any formal empirical evidence. The debate on these issues will continue-albeit hopefully not as long as countries have been mired at the ELB. 


\section{References}

Bank of England. 2014. Inflation Report, August. https://www.bankofengland. co.uk/inflation-report/2014/august-2014.

2016. Inflation Report, November. https://www.bankofengland.co.uk/ inflation-report/2016/november-2016.

Boneva, Lena, Calebe de Roure, and Ben Morley. 2018. "The Impact of the Bank of England's Corporate Bond Purchase Scheme on Yield Spreads." Bank of England Staff Working Paper No. 719. https://www.bankofengland.co.uk/ -/media/boe/files/working-paper/2018/the-impact-of-the-bank-of-englandscorporate-bond-purchase-scheme-on-yield-spreads.pdf?la $=$ en \&hash $=6 \mathrm{C} 4947$ C7C536F27A8ED86165C521F301C01EE9E6.

Brainard, Lael. 2017. "Cross-Border Spillovers of Balance Sheet Normalization." Speech to Board of Governors of the Federal Reserve System, New York, July 11. https://www.federalreserve.gov/newsevents/speech/brainard 20170711a.htm.

Burgess, Stephen, Emilio Fernandez-Corugedo, Charlotta Groth, Richard Harrison, Francesca Monti, Konstantinos Theodoridis, and Matt Waldron. 2013. "Appendices to Working Paper No. 471: The Bank of England's Forecasting Platform: COMPASS, MAPS, EASE, and the Suite of Models." https://www. bankofengland.co.uk/-/media/boe/files/working-paper/2013/the-boes-forecastingplatform-compass-maps-ease-and-the-suite-of-appendix.

Curcuru, Stephanie. 2017. "The Sensitivity of the U.S. Dollar Exchange Rate to Changes in Monetary Policy Expectations." Federal Reserve Board International Finance and Discussion Papers, Notes 2017-09-22.

Curcuru, Stephanie, Steven Kamin, Canlin Li, and Marius Rodriguez. 2018. "International Spillovers of Monetary Policy: Conventional Policy vs. Quantitative Easing." International Finance Discussion Paper 1234, Board of Governors of the Federal Reserve System.

Ferrari, Massimo, Jonathan Kearns, and Andreas Schrimpf. 2017. "Monetary Policy's Rising FX Impact in the Era of Ultra-Low Rates.” Working Paper No. 626, Bank for International Settlements. https://www.bis.org/publ/work626.htm.

Forbes, Kristin. 2014. "The Economic Impact of Sterling's Recent Moves: More Than a Midsummer Night's Dream." Speech at Bank of England, London, October 1. https://www.bankofengland.co.uk/speech/2014/the-economic-impactof-sterlings-recent-moves-more-than-a-midsummer-nights-dream.

2015. “Low Interest Rates: King Midas' Golden Touch?” Speech at Bank of England, London, February 24. https://www.bankofengland.co.uk/ speech/2015/low-interest-rates-king-midas-golden-touch.

2017. "Failure to Lift." Speech at London Business School, London, June 22. https://www.bankofengland.co.uk/speech/2017/failure-to-launch.

Forbes, Kristin, Ida Hjortsoe, and Tsvetelina Nenova. 2018. "The Shocks Matter: Improving Our Estimates of Exchange Rate Pass-Through." Journal of International Economics 114 (September): 255-75. 
Forbes, Kristin, and Francis Warnock. (2012). "Capital Flow Waves: Surges, Stops, Flight and Retrenchment." Journal of International Economics 88, no. 2: 235-51.

Glick, Reuven, and Sylvain Leduc. 2015. "Unconventional Monetary Policy and the Dollar: Conventional Signs, Unconventional Magnitudes.” Working Paper No. 2015-18, Federal Reserve Bank of San Francisco.

Greenlaw, David, James Hamilton, Ethan Harris, and Kenneth West. 2018. "A Skeptical View of the Impact of the Fed's Balance Sheet." U.S. Monetary Policy Forum Paper. https://research.chicagobooth.edu/-/media/research/igm/ docs/2018-usmpf-report.pdf?la=en\&hash=D8BE7A0F78D72A6762918282D5 A56A2E76349AED.

Group of Seven. 2013. "Statement by G7 Finance Ministers and Central Bank Governors." February 12. www.g8.utoronto.ca/finance/fm130212.htm.

Haldane, Andrew, Matt Roberts-Sklar, Tomasz Wieladek, and Chris Young. 2016. "QE: The Story so Far." Bank of England Staff Working Paper 624. https:// www.bankofengland.co.uk/working-paper/2016/qethe-story-so-far.

Hatzius, Jan, Sven Stehn, Nicholas Fawcett, and Karen Reichgott. 2017. "Policy Rate vs. Balance Sheet Spillovers." Goldman Sachs Economics Research, Global Economics Analyst, July 28.

Joyce, Michael, Matthew Tong, and Robert Woods. 2011. “The United Kingdom's Quantitative Easing Policy: Design, Operation and Impact. Bank of England Quarterly Bulletin, third quarter. https://papers.ssrn.com/sol3/papers.cfm? abstract_id=1933696.

Nakamura, Emi, and Jón Steinsson. 2018. "High-Frequency Identification of Monetary Non-neutrality: The Information Effect." Quarterly Journal of Economics 133, no. 3: $1283-1330$.

Neely, Christopher. 2015. "Unconventional Monetary Policy had Large International Effects." Journal of Banking and Finance 52: 101-11.

Rey, Hélène. 2013. "Dilemma Not Trilemma: The Global Financial Cycle and Monetary Policy Independence.” Proceedings of the Jackson Hole Symposium, sponsored by Federal Reserve Bank of Kansas City. https://www.kansascityfed. org/publicat/sympos/2013/2013Rey.pdf.

Weale, Martin, and Tomasz Wieladek. 2016. "What Are the Macroeconomic Effects of Asset Purchases?” Journal of Monetary Economics 79: 81-93. 